\title{
Investigating Migrants Adaptation Process through Gardening Practices in Community Gardens
}

\author{
Imas Agustina ${ }^{1}$, Ruth Beilin ${ }^{2}$ \\ ${ }^{1}$ Melbourne School of Land and Environment, \\ University of Melbourne, Victoria 3010, Australia \\ 2 Department of Resource Management and Geography, \\ University of Melbourne, Victoria 3010, Australia \\ imas_agustina@yahoo.com
}

\begin{abstract}
Investigation approach to migrants adaptation process inhostcountries has always been place specific, in order to understand the whole connections to all aspect of life. In Melbourne, community gardens have been a place where immigrants start their interaction with others. The literature argues that the gardens can foster social inclusion, while at the same time providing space to preserve their cultural identity. This paper will investigate the adaptation of migrants within the garden setting, by considering the extent to which cultural practices in gardening affect their ability to adapt to the host country (Australia). The findings confirm a complex relationship between historical garden practices/culture and the reality of practices in the community gardens.
\end{abstract}

Keywords: self-built housing, donated housing, lifestyle, social interaction, adjustments

eISSN 2514-751X @ 2018. The Authors. Published for AMER ABRA cE-Bs by e-International Publishing House, Ltd., UK. This is an open-access article under the CC BY-NC-ND license (http://creativecommons.org/licenses/bync-nd/4.0/). Peer-review under responsibility of AMER (Association of Malaysian Environment-Behaviour Researchers), ABRA (Association of Behavioural Researchers on Asians) and cE-Bs (Centre for EnvironmentBehaviour Studies), Faculty of Architecture, Planning \& Surveying, Universiti Teknologi MARA, Malaysia.

DOI: https://doi.org/10.21834/aje-bs.v3i6.242 


\subsection{Introduction}

Many studies have focused on migrants' adaptation to different cultures across different settings, such as in schools, workplaces, and in the community (see Kosic, 2002; Matsunaga, echt, Elek, \& Ndiaye, 2010; Shalom \& orenczyk, 2004). owever, such studies are still limited, particularly in community garden settings, despite the current discussion on advantages of involvement in community gardens for immigrants (such as in Baker, 2004; Bartolomei, Corkery, Judd, \& Thompson, 2003). On the other hand, these days, the increased involvement of migrants in community gardens in Melbourne can be seen in the increase of the gardens for public housings (whose tenants are mostly migrants), from 14 gardens in 2002 to 22 gardens in 2010 (Cultivating Community, 2009; Eat Your City, 2010).

Study in particular setting is important, considering community gardens' role in providing space or land to preserve migrants' cultural identity (Baker, 2004; Bartolomei etal., 2003; Teig et al., 2009; Thompson, Corkery, \& Judd, 2007), presumably through gardening practices, or through the sharing of food that they produce. Besides, by having a chance to meet and interact with other people from different countries makes it possible for the migrant gardeners to exchange their gardening practices to find the best way of growing plants and vegetables. These situations have brought potential benefits either by providing a feeling of being athome (Bartolomei et al., 2003), or creating a sense of belonging with the new place and society (Baker,2004), respectively. Thispaper, therefore, attemptstoinvestigate the process of migrants' adaptation to a new place in the community gardens setting, which is approached through exploring their gardening practices as well as multicultural interactions occurred.

\subsection{Literature Review}

\subsection{Cultural Identity and the Sense of Belonging}

According to the Australian Ethnic Affairs Council, cultural identity is defined as "the sense of belonging and attachment to a particular way of living, associated with the historical experience of agroup of people" $(1977$, p. 3). This sense of belonging is generally influenced by the individual's process of living in their community, where a culture is unconsciously created through shared premises, values, definitions, beliefs, and patterning activities (Adler, 2002). For migrants living in different cultures and places, the process of creating a sense of belonging is influenced by both their original culture and the host culture (Cleveland, Laroche, Pons, \& Kastoun, 2009). This process is usually denoted by the term 'acculturation'. In its initial discourse (i.e. Melting Pot Theory), acculturation has a tendency to assimilation (Park, 1914 in Padilla \& Perez, 2003), which is a term to indicate a condition where immigrants finally adopt the cultural patterns of a dominant/host group in order to minimize conflicts (Satia-Abouta, Patterson, Neuhouser, \& Elder, 2002).

However, there was a shift of acculturation discourse as the number of international migrants increased and thus it changed the pattern of mix environments created. According to the 2009 United Nations uman Development Report, the number of international migrants has been increasing from 191 million people in 2005 to about 200 million people in mid-2010 (UN, 2009 in Oneworld Guides, 2010). Moreover, in Melbourne alone, immigrants have 
counted for $40 \%$ of the total population (The State of Victoria DPCD, 2007; Victorian Multicultural Commission, 2010) that provide the environment with 200 different cultures potentially interact with each other. This fact confirms the idea of cultural pluralism, ( orace Kallen, 1915 in Whitfield, 1999 and Linton and erskovits, 1936 in Padilla \& Perez, 2003) which argues that the process of acculturation would not only involve and affect two different cultures, but more cultures, given the opportunity to interact with each other regularly.

Lately, Berry (1980 in Konig, 2009) expanded this perspective by revealing four different results of acculturation, namely integration, assimilation, segregation and marginalization. The terms have been widely used by other scholars in investigating migrants' adaptation in various settings (see Bhatia \& Ram, 2009; Cleveland et al., 2009; Shalom \& orenczyk, 2004). First, integration is a position where the positive value of interacting cultures is preserved. Assimilation is defined when the new/majority culture is to be chosen rather than the culture of origin. Separation can be attributed to the way the individuals insist on holding on to their primary culture. Lastly, marginalization is a condition where neither primary culture nor host/majority culture is preserved. To put this concept in place, the last pattern is mostly seen as a kind of cultural transmutation (Mendoza and Martinez, 1981 in Cleveland et al., 2009), or hybridity (Robinson, 2006), which is emergence of a new culture, not the loss of practical cultures involved in the interaction.

\subsection{Migrants' Adaptation in Community Gardens}

Apart from the involvement of migrants in the gardening activities, community gardens are generally understood as places where plants or food are grown in communal settings (Brown, 2008; Kingsley, Townsend, \& Wilson, 2009; Teig et al., 2009). Their role in providing a relatively cheap food supply through direct interaction with nature (i.e. gardening) has been proposed as a solution for both urban food insecurity and "traditional attachment to the soil and natural environment" (Moller, 2005; Thompson et al., 2007). Recently, since migrants have become involved in gardening activities, defining the traditional attachment to the soils has become complicated, leading to the notion that community gardens may enhance the migrants' cultural identities or spirituality (Baker, 2004; Kingsley et al., 2009; Thompson et al., 2007).

It is argued that with the individual's right to decide not only how to use the garden, but also how to shape it by themselves, the unique characteristic of gardening practices can be found in migrants' garden plots (Joseph, 1999 in Baker, 2004; elzer, 1994 in Corlett et al., 2003). This is why Baker (2004, p. 305) links gardening activities in community gardens to a process of place construction, whereby migrants produce a 'sense of place'. Interestingly, the significance of revealing cultural identity by migrants in this setting, as discussed above, is questionable. It is due to the existence of social connections, which emphasize more similarity than uniqueness (Sasja, 1999), in community gardens as well (Baker, 2004; Corlett, Dean, \& Grivetty, 2003; Kingsley et al., 2009; Teig et al., 2009; Thompson et al., 2007).

As Konig (2009) argues, adaptation involves tension between maintaining and developing personal identity, and drawing close to a new environment. The state of adaptation is indicated through a created sense of belonging or a sense of place in its context. In the current 
literature, however, the actual process by which daily practices of living in these gardening spaces transforms into a 'sense of place' is not clear. Furthermore, the fact that not all gardeners involved in community gardens have a gardening background in their home country raises questions about how significant the preservation of gardening practices from their country of origin is for them, compared to the significance of adopting the new practices in the host country.

\subsection{Methodology}

As it is commonly used by other studies focusing on cultures and migrant adaptations (Airries \& Clawson, 1994; Christie, 2004; Gombay, 2005; Matsunaga et al., 2010), case study methodology was used in this research. It is in order to "understand everyday practices and their meanings to those involved" ( artley, 2004, p. 325), which in this case were migrant gardeners. The research was conducted by interviewing 11 migrant gardeners out of 150 gardeners registered as tenants in five community gardens studied, and two Garden Support Workers who are responsible for managing the day-to-day gardening activities. The participants were asked several open- ended questions. They were approached through the use of a snowballing technique to "establish a good correspondence between research questions and sampling" (Bryman, 2004, p. 334). The characteristics of participants involved in this research are shown in the table below.

Table 1: Research Participants

\begin{tabular}{|c|c|c|c|c|c|c|c|}
\hline arden (Age) & Participant & $\begin{array}{l}\text { Country of } \\
\text { Origin/ } \\
\text { Culture } \\
\text { Group } \\
\text { in the } \\
\text { Gardens }\end{array}$ & $\begin{array}{l}\text { Minority/ } \\
\text { Majority } \\
\text { Group of } \\
\text { Ethnicity }\end{array}$ & $\begin{array}{c}\text { In } \\
\text { Melbourne }\end{array}$ & Gender & Age & $\begin{array}{c}\text { Plot } \\
\text { ownership }\end{array}$ \\
\hline \begin{tabular}{|l|}
$\begin{array}{l}\text { Fitzroy (8 } \\
\text { years) }\end{array}$ \\
\end{tabular} & F.1 & $\begin{array}{c}\text { China - } \\
\text { Guangdong }\end{array}$ & Majority & 10 years & Male & $70+$ & 7 years \\
\hline \multirow[t]{2}{*}{$\begin{array}{l}\text { llingwood (7 } \\
\text { years) }\end{array}$} & Co.1 & $\begin{array}{l}\text { lalaysia - } \\
\text { Chinese }\end{array}$ & Minority & 16 years & Female & 58 & 7 years \\
\hline & Co.2 & Malaysia & Minority & 27 years & Female & $50-60$ & 3 years \\
\hline \multirow{4}{*}{\begin{tabular}{|c} 
Neill St. (3 \\
month $\left.^{*}\right)$
\end{tabular}} & Ca.1 & Vietnam & Majority & 22 years & Female & 57 & 1 month \\
\hline & Ca.2 & $\begin{array}{l}\text { Greece } \\
\text { - born in } \\
\text { Melbourne }\end{array}$ & Majority & 43 years & Female & 43 & 4 years \\
\hline & Ca.3 & Sri Lanka & Minority & 15 years & Male & 67 & $\begin{array}{c}\text { Help } \\
\text { Voluntarily } \\
\text { since } 2005 \\
--5 \text { years }\end{array}$ \\
\hline & Ca.4 & Africa & Minority & 17 years & Female & $35-40$ & 3 months \\
\hline
\end{tabular}


Agustina, I. \& Beilin, R. / Asian Journal of Environment-Behaviour Studies (ajE-Bs), 3(6) Jan / Feb 2018 (p121-130)

\begin{tabular}{|lrrrrrrr|}
\hline $\begin{array}{l}\text { Park St. (3 } \\
\text { years) }\end{array}$ & P.1 & 3elarus, Russia & Majority & 20 years & Female & 63 & 7 months \\
\cline { 2 - 7 } & P.2 & Lebanon & Minority & 30 years & Female & 66 & 3 years \\
\cline { 2 - 7 } & P.3 & Thailand & Minority & 6 years & Female & 47 & 3 years \\
\hline $\begin{array}{l}\text { Jnion St. (8 } \\
\text { years) }\end{array}$ & U.1 & Greece & Majority & 38 years & Female & $63-64$ & 8 years \\
\hline
\end{tabular}

Neill -t. garden is a newly(established garden, replacing the old garden in the area. 7wo participants are those inuolued in the preuious garden, while the other two are nouice gardeners.

\subsection{Results and Discussions}

It was found that the plants grown across the allotments vary (only six plants are generally common out of 40 plants mentioned during the interviews), but it is not necessarily attributable to people's cultures. Although the gardeners noticed general ideas about the relationship between plants grown and the gardeners' diet (which is a product of culture), planting culturally related vegetables from other countries are also commonly found. When asked about the relationship between what they grew and their identities, almost all participants were doubtful that visitors would recognize their identity through their plots (their created landscape), particularly because they grew various kinds of vegetables, not only ones from their own country. The participants could not even distinguish other people's plots without knowing where the owner came from because most vegetables are not culturally exclusive in the context of the gardens. From the way the participants expressed their process of choosing plants, only a few of them linked their practice back to their gardens in their home countries. Those who have first-hand gardening experience back there. The other gardeners simply connected their gardening practices to their diet, the availability and accessibility of seeds, and/or the kindness of other gardeners (or support workers) in giving them plants.

In regards to gardening techniques, participants did not simply replicate what they did back in their home country, they were also interested in cultivating good vegetables. This indicates that a significant connection to gardening in a country of origin (as represented by having a common garden and practices in hostcountries) did not take place, unlike the findings made by Thompson et al., (2007). This finding can be linked to gardeners' absence or limit of gardening experience in their home country. On the other hand, another finding confirms that some experienced gardeners feel more attached to their home country when they grow similar plants, utilize the same techniques, or plant the same things as they did in their past garden (e.g. ornaments). owever, the gardeners not only replicate gardening practices from their country of origin. Rather, they continue to learn more practices in their host country. This relates to their interest in gardening, as well as the different physical conditions that force them to adopt different techniques to be acknowledged as a good gardener, no matter what practices they use.

Based on the above findings, the research confirms that the reality of practices in the community gardens may have similar characteristics to the historical gardening practices or 
culture to the migrants' gardens in their country of origin. This, to some extent, confirms the idea that community gardens are places where traditional agriculture skills remain essential in daily life, as explained by elzer (1994 in Corlett et al., 2003). Although, differentfrom the claims of Corlettetal., (2003), theabovefindings indicate that plants grown in the gardens cannot always be viewed as cultural markers, or as items that provide consumers with common identities and a means to reinforce cultural practices. It was also found in this study that the degree to which the gardeners desire to preserve their past garden practices depends on the range of historical connections to the past gardens, and to cultural-related food experienced by the gardeners. On the other hand, gardeners' concern for people's recognition in the garden also indicates their concern for building connections in the new community.

The process of building a connection to the new community in this setting is highly influenced by the level of multicultural interactions (Thompson et al. 2007; Teig et al., 2009). It was found that interactions in the gardens increased when they exchange produce, particularly when they had plenty of seeds or harvest lots of vegetables. This exchange happened not only between those who are from the same country of origin, and not only those who ask for their own culturally related plants. Fascinatingly, having a multicultural environment might be an impetus for interaction, since it is common for the gardeners to walk around and look at other plots, noticing the differences in plant types and gardening techniques. owever, when the gardeners were asked about how they learn to garden, personal experience is the most frequent answer. The second way is learning from friends (inside and outside the garden), followed by media (book, TV programs, and internets), family, and the support workers. This is different from what the current literature says that learning from other gardeners is the expectation of how migrant gardeners to get started. owever, this is understandable given the two obstacles found; namely, the language barrier and the subsequent decreased opportunity to encounter other gardeners casually. The obstacles tend to reinforce an intra-cultural association, rather than a cross-cultural association, and limit the exchange practices that could occur. An interesting finding is that, in these two circumstances, the support workers provide a significant role in transferring gardening knowledge from one gardener to another, given their responsibility to assist the day- to-day gardening activities. Thus, it is evident in this research that certain gardeners, who do not come to the garden for social well-being, are able to adapt and experience acculturation, besides learning and developing skills.

Migrant gardeners' adaptation to food and gardening practices ultimately affects the garden-culture relationships, especially in this case, where the participant gardeners have been living in Melbourne for atleast 10 years. It was found that migrant adaptation complicated their attachment to the gardening practices and cultures from their country of origin. For example, dietary practice, as a way to connect migrants' gardening practices to their culture of origin, can be bias considering that dietary acculturation is evident in this research. This is consistent with studies by Christie (2004) and Satia-Abouta, et al., (2002). In the context of food and garden, the acculturation process begins with physical adaptation by firstly identifying what is growing well, followed by dietary acculturation by later deciding what to grow more of. This is why the gardeners tend to accept plants or seeds offered by other 
gardeners or the support workers, even if they do not know how to grow the plants or what the benefits are for them. After harvesting the vegetables, they then decide to either continue to grow it or give it up in the next growing season. Therefore, it is possible to find that certain culturally related plants or gardening techniques have become common across the allotments. With these similarities, migrant gardeners most likely experience feelings of 'sameness' or 'wholeness'; a sense of community. Gardeners from both the majority language and the minority language groups confirmed this. In other words, these similarities may indicate the degree of multicultural interaction that occurs in the gardens- even unintentionally.

Finally, the research came up with two types of Berry's acculturation. Assimilation and integration emerged as the most frequent types of experience for migrants - acculturation best describes what happened in the gardens. More often than not, assimilation occurred due to the local adaptation, when the gardeners dealt with different types of soils, weather, availability of fertilizers, limited space forgrowing, and specific restrictions set up by Cultivating Community. These factors provided the gardeners with no choice but to grow and use what was available, and avoid restricted practices, even if they were related to their country of origin (e.g. restrictions to grow trees). In other words, the decision to adapt cannot be separated from the boundary set up by the local authority (in this case Cultivating Community and $D$ S), representing the power relation between the gardeners and the host culture. Although one culture is dominant in each garden, its power over other ethnic groups is still limited. On the one hand, it can prevent the domination of one cultural group, but it also implies that assimilation is still intended as an ideal form of acculturation in practice, as discussed in the first acculturation concept (Melting Pot theory).

\subsection{Conclusion}

To conclude, community gardens provide a space to make the unfamiliar familiar. The gardening activities are re-creating the sense of belonging for migrants, either by transplanting the gardening practices from their country of origin or creating a connection to the new community. owever, the cultural association evidenced in this research is only limited to those who have first-hand gardening experience back in their home country and to those from the minority group, reinforced by the multicultural environment. The rest are mostly connected to their culture of origin through their dietary practices, which are prone to changes due to adaptation, and thus reveal dietary acculturation. Social connection, gained through adaptation and acculturation, is experienced by almost all gardeners in such gardens, although not all gardeners involved intend to get social well-being. If social connection is the objective in community gardens, there is a need to resolve two main obstacles; namely, the language barrier experienced by many migrants and the subsequent difficulty in encountering other gardeners. In regard to Berry's classification, this research shows that it is useful to recognize the changes people bring to the garden. By doing this, it makes us possible to approximate the presence of garden-culture relationships, even though this research cannot answer for how strong the relationship is. 


\section{Acknowledgement}

We thank Thomas Jones, Hannah Maloney, Jeremy, and Daniel Murphy for their time and help from the preliminary survey to the final one. Special thanks to Kristen Lyons and J. Boyd for the constructive comments and feedback on the final thesis report that contribute to this article.

\section{References}

Adler, P. (2002). Beyond Cultural Identity: Reflections on Multiculturalism. Journal. Retrieved from http://www.mediate.com/articles/adler3.cfm

Airries, C. A., \& Clawson, D. L. (1994). Vietnamese Market Gardens in New Orleans. Geographical Review, 84(1), $16-31$.

Australian Ethnic Affairs Council. (1977). Australia as a Multicultural Society. Unpublished manuscript, Canberra.

Baker, L. E. (2004). Tending Cultural Landscapes and Food Citizenship in Toronto's Community Gardens. GeographicalReview, 94(3),305-325.

Balbo, M., \& Marconi, G. (2006). International migration, diversity and urban governance in cities of the South. Habitat International, 30(3), $706-715$.

Bartolomei, L., Corkery, L., Judd, B., \& Thompson, S. (2003). A Bountiful Harvest: Community Gardens and Neighbourhood Renewal in Waterloo, Available from http://www.housing.nsw.gov. au/NR/rdonlyres/546938EDF0E9-433F-9861-3093F11664E6/0/ A Bountiful Harvest.pdf

Bhatia, S., \& Ram, A. (2009). Theorizing Identity in Transnational and Diaspora Cultures: A Critical Approach to Acculturation International Journal of Intercultural Relations 33(2009), 140 - 149.

Boyatzis, R. E. (1998). Transforming Qualitative Information: Thematic Analysis and Code Development. California: SAGE Publications.

Brown, S. (2008). Urban Agriculture? Is 7here Now an Opportunity for A Viable Small-Scale Sustainable Agriculture to Emerge in Brisbane, Australia?. Charles Stuart University.

Bryman, A. (2004). -Social Research Methods. Oxford: Oxford University Press.

Christie, M. E. (2004). Kitchenspace, Fiestas, and Cultural Reproduction in Mexican House-Lot Gardens. Geographical Review, 94(3), 368 - 390.

Cleveland, M., Laroche, M., Pons, F., \& Kastoun, R. (2009). Acculturation and Consumption: Textures of Cultural Adaptation. International Journal of Intercultural Relations, 33(2009), 196 - 212.

Commonwealth of Australia (2001). Natural and Cultural Heritage, Available from $\mathrm{http}: / /$ books.google.com.au/books?id=7rhAfPzRqmUC\&printsec=frontcover\#v=onepage\&q\&f=false

Corlett, J. L., Dean, E. A., \& Grivetty, L. E. (2003). Among Gardens: Botanical Diversity in An Urban Setting. Economic Botany, 57(3), $365-379$.

Cultivating Community. (2009). Cultivating Community Employment Information Kit. from 
http://www.sustainablemelbourne.com/wp-content/uploads/2009/02/cultivating-community-community-gardenteam-leader-job-description.pdf

Eat Your City. (2010, February). Sustainable Living Festival. Retrieved 21 August 2010, from http://festival.slf.org.au/program/talk/ eat-your-city-community-responses-food-security.

Gombay, N. (2005). Shifting Identities in A Shifting World: Food, Place, Community, and the Politics of Scale in an Inuit Settlement. Environment and Planning, 23(Society and Space), 415 - 433.

Hartley, J. (2004). Case Study Research. In C. Cassel \& G. Symon (Eds.), Essential Guide to Qualitatvie Methods in Organizational Research Available from http://books.google.com.au/books?id=1rPSA16gxlw C\&printsec=frontcover\#v=onepage \&q\&f=false

Hedges, B. (2004). Sampling. In C. Seale (Ed.), Social Research Methods: A Reader(pp. 63-72). London, New York: Routledge StudentReader.

Holmes, K. (2008). Reading the Garden? The-settlement of Australia. Carlton, Victoria: Melbourne University Publishing.

Kingsley, J. Y., \& Townsend, M. (2006). ‘Dig In’ to Social Capital: Community Gardens as Mechanism for Growing Urban Social Connectedness. Urban Policy and Research, 24(4), 525 - 537.

Kingsley,j.Y., Townsend, M., \&Wilson, C.(2009). Cultivating health and wellbeing: members' perceptions of the health benefits of a Port Melbourne community garden. Leisure Studies, 28(2), 207-219.

Konig,J.(2009).MovingExperience:DialoguesbetweenPersonalCultural Positions. Culture Psychology, 15(1), 97 119.

Kosic, A. (2002). Acculturation Attitudes, Need for Cognitive Closure, and Adaptation of Immigrants. Journal of Social Psychology, 142(2), 179-201.

Matsunaga, M., echt, M. L., Elek, E., \& Ndiaye, K. (2010). Ethnic Identity Development and Acculturation: A Longitudinal Analysis of Mexican- Heritage Youth in the Southwest United States. Journal of Cross (Cultural Psychology, 41(3), 410 - 427.

Moller, V. (2005). Attitudes to Food Gardening from a Generational Perspective. Journal of Intergenerational Relationships, 3(2), 63-80.

Oneworld Guides (2010). International Migrations Guide. Journal, October 2010. Retrieved from http://uk.oneworld.net/guides/ migration?gclid=CMqch-710acCFQMb6wodlhb0sQ

Padilla, A. M., \& Perez, W. (2003). Acculturation, Social Identity, and Social Cognition: A New Perspective. Hispanic Journal of Behavioral Sciences, 25(1), $35-55$.

Robinson, J. (2006). Ordinary Cities? Between Modernity and Development. London and New York: Routledge.

Sasja, T. (1999). Constructions of Cultural Identity: Multiculturalism and Exclusion. Political -tudies, 47(1), 17 - 31.

Satia-Abouta, J., Patterson, R. E., Neuhouser, M. L., \& Elder, J. (2002). DietaryAcculturation:Applicationsto Nutrition Researchand Dietetics. Journal of the American Dietetic Association, 102(8), 1105 - 1118.

Shalom, U. B., \& orenczyk, G. (2004). Cultural Identity and Adaptation in an Assimilative Setting: Immigrant Soldiers from the Former Soviet Union in Israel. International Journal of Intercultural Relations, 28(2004), 461 - 479. 
Teig, E., Amulya, J., Bardwell, L., Buchenau, M., Marshall, J. A., \& Litt, J. S. (2009). Collective efficacy in Denver, Colorado: Strengthening neighborhoodsandhealththroughcommunitygardens. Health\&Place, 15(4), 1115 - 1122.

The State of Victoria DPCD. (2007). Victoria's Overseas Born. Info Sheet 6 Retrieved 26 April 2010, from http://www.dse.vic.gov.au/

CA256F310024B628/0/C6E21C1547A3922CCA2573A600076E5A/\$File/DPCD+6-Overseas+born.pdf.

Thompson, S., Corkery, L., \& Judd, B. (2007). The Role of Community Gardens in sustaining Healthy Communities.

Paper presented at the State of Australian Cities National Conference. from

http://www.fbe. unsw.edu.au/cityfutures/SOAC/theroleofcommunitygardens.pdf.

Victorian Multicultural Commission. (2010). Population and Migration. Retrieved 22 November 2010, from http://www.multicultural.vic.gov. au/all-of-us.

Whitfield, S. J. (1999). America's Melting Pot Ideal and orace Kallen. Society, September, 01. 